\title{
LOW FREQUENCY OF CHRONIC BIOLOGICAL FALSE POSITIVE REACTORS TO SEROLOGICAL TESTS FOR SYPHILIS IN RHEUMATOID ARTHRITIS AND ANKYLOSING SPONDYLITIS
}

\author{
BY \\ O. P. SALO, K. SIEVERS, P. AHVONEN, AND K. AHO \\ From the State Serum Institute, Helsinki, Rheumatism Foundation Hospital, Heinola, \\ and Department of Hygiene, University of Helsinki, Finland
}

In the so-called collagen diseases there is considerable overlapping of both clinical signs and serological phenomena. Elevated serum globulins, L.E.-cells, rheumatoid factors, and chronic biological false positive (CBFP) serological reactions for syphilis have been observed both in rheumatoid arthritis (RA) and in systemic lupus erythematosus (SLE). The frequency of RA among CBFPreactors has been estimated at about 10 per cent. or even less (Wuepper, Bodily, and Tuffanelli, 1966; Putkonen, Jokinen, Lassus, and Mustakallio, 1967; Miller, Brodey, and Hill, 1957). On the other hand, the frequency of CBFP-reactors among patients with RA has been reported to be in the range of 5 to $11 \cdot 6$ per cent. (Moore and Mohr, 1952; Waldenström and Winblad, 1958; Kievitz, Goslings, Schuit, and Hijmans, 1956). These figures seem high considering the common occurrence of rheumatoid arthritis (Kellgren, 1966) and the low percentage of positive serological tests for syphilis in unselected cases.

We have therefore studied the occurrence of CBFP reactions in a large series of patients treated at a specialized rheumatism hospital and diagnosed according to uniform criteria.

\section{Material and Methods}

The present series is based on 14,676 patients treated during the years 1952-1966 at the Rheumatism Foundation Hospital, Heinola. The majority had either rheumatoid arthritis (about 10,500) or ankylosing spondylitis (about 400), systemic lupus erythematosus was diagnosed in about 150 , and the others had degenerative joint disease, rheumatic fever, or some other joint disease. The average age was about 40 years, less than 10 per cent. of the total being over 60 years of age.

Sera from all patients were screened by the VDRL test. In 1952-1963 the screening was performed at the Rheumatism Foundation Hospital and the sera giving positive reactions were re-tested at the State Serum Institute, Helsinki. From 1963 onwards, the screening was performed at the State Serum Institute.
The TPI test was available from 1961 and the FTAABS test from 1966. In 1963 the patients with positive serology were re-examined. Sera were obtained from about half of the positive cases and subjected to the TPI test. A second re-examination was carried out in 1967 to control the cases treated from 1963 to 1966; these were examined by both the TPI and FTA-ABS tests.

The TPI test was done by the technique of Nelson and Mayer (1949) and Nelson and Diesendruck (1951), with small modifications. The FTA-ABS test was performed according to the provisional technique published in 1965 by the Venereal Disease Laboratory of the Communicable Disease Center, Atlanta, Georgia. The VDRL test was performed according to standard techniques, using Sitolipin as an antigen (S.T.S. Manual, 1959; Uroma and Tommila, 1951).

\section{Results}

The VDRL test was positive in 97 patients, 78 of whom had rheumatoid arthritis, four ankylosing spondylitis, five systemic lupus erythematosus, and ten other joint conditions.

Clinical information about syphilis was obtained from 36 of the 82 patients with RA or AS. This information, together with the results of the treponemal antibody tests, is presented in the Table. The results of these tests were fairly similar. In only one case was the TPI test negative and the FTAABS test positive; this patient had congenital syphilis.

\section{TABLE}

CLINICAL INFORMATION ABOUT SYPHILIS AND THE RESULTS OF THE TREPONEMAL ANTIBODY TESTS IN 36 PATIENTS WITH RHEUMATOID ARTHRITIS OR ANKYLOSING SPONDYLITIS

\begin{tabular}{|c|c|c|}
\hline Clinical Information & $\begin{array}{c}\text { Number } \\
\text { of } \\
\text { patients }\end{array}$ & $\begin{array}{c}\text { Treponemal } \\
\text { Antibodies } \\
\text { (positive/tested) }\end{array}$ \\
\hline $\begin{array}{l}\text { Previous diagnosis and treatment } \\
\text { Clinical neurosyphilis } \ldots \\
\text { Aortitis . } \\
\text { Positive serology in the spouse } \ldots \\
\text { Congenital syphilis } \\
\text { Positive serology in the mother. . }\end{array}$ & $\begin{array}{r}24 \\
4 \\
2 \\
2 \\
2 \\
2\end{array}$ & $\begin{array}{l}11 / 11 \\
1 / 1 \\
\overline{2 / 2} \\
1 / 1\end{array}$ \\
\hline Total & 36 & $15 / 15$ \\
\hline
\end{tabular}


For the other 46 patients with rheumatoid arthritis or ankylosing spondylitis there was no information about syphilis; 24 sera were examined by treponemal antibody tests, and the results are presented in the Figure. In eighteen of the 46 cases the positive VDRL result was of a transient nature. The patients for which treponemal antibody tests were performed are shown separately in the Figure. The probable number of positive treponemal antibody tests among the 22 in whom the tests were not performed was calculated according to the findings in the 24 in which the tests were performed. These calculations yielded only four chronic BFP reactors among the patients with rheumatoid arthritis or ankylosing spondylitis, less than 0.4 per thousand.

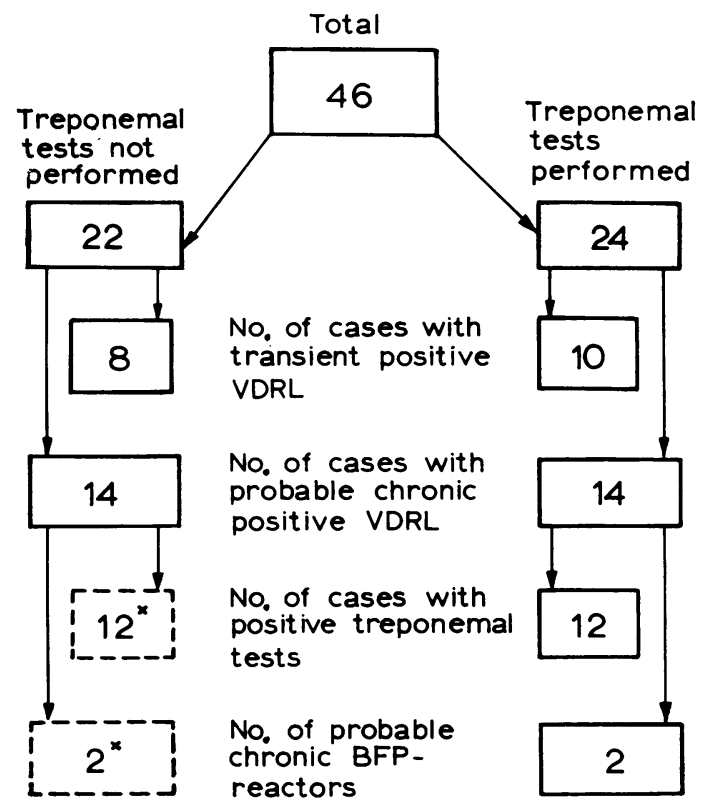

Figure.-Results of treponemal antibody tests in patients for whom no clinical information about syphilis was available.

* Figures surrounded by dotted lines are calculated on the basis of the findings in the group in which the treponemal tests were performed.

Of the 150 patients diagnosed as having systemic lupus erythematosus, only five had a positive VDRL test. The TPI test was performed in four of them, and two were TPI positive, one with no information about syphilis and the other with congenital syphilis treated as a child. One of the two TPI-negative patients had syphilis treated at the primary stage and the other denied having had syphilis. The patient in whom the TPI test was not done had a serologically-positive husband. This leaves only one definite false positive reactor in the group of $\mathbf{1 5 0}$ patients with SLE.
The present series included ten patients with a positive VDRL test suffering from diseases other than rheumatoid arthritis, ankylosing spondylitis, or SLE; in two of them, syphilis had been treated in the past, one having had clinical neurosyphilis and the other syphilitic aortitis. In six cases there was no available information about syphilis.

\section{Discussion}

The frequency of positive serological reactions for syphilis in a given series varies greatly with the composition of the series and also with the number and sensitivity of the serological tests employed. In the present series only the VDRL test was used as a screening procedure. At the present level of sensitivity this test detects about 90 per cent. of the chronic BFP reactions that can be detected with a battery of five tests (Wassermann, Cholesterol Wassermann, Kahn, Kolmer, VDRL: Lassus 1967). With these five tests the frequency of positive reactors among patients with definite SLE is 29 per cent. (Putkonen and others, 1967).

The incidence of false positive serological tests for syphilis in patients with rheumatoid arthritis has been estimated at 5 to 10 per cent. (Moore and Mohr, 1952; Kievitz and others, 1956). In the present series, the calculated frequency was only about 2 per thousand ( 22 cases), and in the majority of these cases the positivity was transient. The relative frequency of transient positive reactions may be related to intercurrent infections that are known to exacerbate the rheumatic disease and can thus lead to hospitalization of the patient.

The mean age of the patients with rheumatoid arthritis or ankylosing spondylitis, in the present series, was about 40 years, less than 10 per cent. being over 60 years of age. It has been reported that the frequency of positive serological tests for syphilis is markedly higher in the older age groups than in the general population (Tuffanelli, 1966). The same holds true for rheumatoid factors (Heimer, Levin, and Rudd, 1963). It may be difficult to differentiate between disease-association and age- $\widetilde{\sigma}$ association in a series including many old persons with rheumatic complaints. The present series, consisting of young and middle-aged patients, indicates that the incidence of the chronic BFP phenomenon in rheumatoid arthritis and ankylosing spondylitis is very low, hardly any higher than in the general population.

The present series included about 150 patients with systemic lupus erythematosus; a positive VDRL test was found in five, only one of whom was a definite CBFP-reactor. The reported frequency of $\Omega$ CBFP-reactors among patients with SLE varies from 
0 to 44 per cent. (Shulman, 1963), depending, among other things, on the diagnostic criteria. The patients in the present series were hospitalized mainly because of arthritic complaints. It seems possible that this group represents borderline cases between rheumatoid arthritis and SLE, so that the frequency of CBFP-reactors is lower than in many other series.

\section{Summary}

Serological tests for syphilis have been studied in patients treated in 1952-1966 at the Rheumatism
Foundation Hospital, Heinola, Finland. All were screened with the VDRL test, which was positive in 97 cases $(6 \cdot 6$ per thousand).

Of the positive cases, 82 had rheumatoid arthritis or ankylosing spondylitis. Clinical information and/or treponemal antibody tests, showed that sixty of these patients had syphilis. The great majority of the false positive reactions were transient, and the frequency of probable chronic BFP reactors was less than 0.4 per thousand.

\section{REFERENCES}

Heimer, R., Levin, F. M., and Rudd, E. (1963). Amer. J. Med., 35, 175 (Globulins resembling rheumatoid factor in serum of the aged).

Kellgren, J. H. (1966). Arthr. and Rheum., 9, 658 (Epidemiology of rheumatoid arthritis).

Kievits, J. H., Goslings, J., Schuit, H. R. E., and Hijmans, W. (1956). Ann. rheum. Dis., 15, 211 (Rheumatoid arthritis and the positive L.E.-Cell phenomenon).

Lassus, A. (1967). Personal communication.

Miller, J. L., Brodey, M., and Hill, J. H. (1957). J. Amer. med. Ass., 164, 1461 (Studies on significance of biologic false-positive reaction).

Moore, J. E., and Mohr, C. F. (1952). Ibid., 150, 467 (Biologically false positive serologic tests for syphilis: Type, incidence, and cause).

Nelson, R. A., Jr., and Diesendruck, J. A. (1951). J. Immunol., 66, 667 (Studies on treponemal immobilizing antibodies in syphilis. I. Techniques of measurement and factors influencing immobilization).

— and Mayer, M. M. (1949). J. exp. Med., 89, 369 (Immobilization of Treponema pallidum in vitro by antibody produced in syphilitic infection).

Putkonen, T., Jokinen, E. J., Lassus, A., and Mustakallio, K. K. (1967). Acta derm.-vener. (Stockh.), 47, 83 (Chronic biologic false positive seroreactions for syphilis as a harbinger of systemic lupus erythematosus).

"Serologic Tests for Syphilis. 1959 Manual." $\quad$ U.S. Department of Health, Education, and Welfare. Public Health Service.

Shulman, L. E. (1963). J. chron. Dis., 16, 889 (Serologic abnormalities in systemic lupus erythematosus).

Tuffanelli, D. L. (1966). Brit. J. vener. Dis., 42, 40 (Ageing and false positive reactions for syphilis).

Uroma, E., and Tommila, V. (1951). Ann. Med. exp. Biol. Fenn., 29, 315 (Results obtained with VDRL slide flocculation test with Sitolipin as the antigen).

Waldenström, J., and Winblad, S. (1958). Acta rheum. scand., 4, 3 (Some observations on the relationship of certain serological reactions in various diseases with hypergammaglobulinemia).

Wuepper, K. D., Bodily, H. L., and Tuffanelli, D. L. (1966). Arch. Derm. (Chicago), 94, 152 (Serologic tests for syphilis and the false-positive reactor).

La rareté de la positivité fausse chronique des réactions à la cardiolipine $(V D R L)$ en cas de polyarthrite rhumatoide et de spondylarthrite ankylosante

\section{RÉSUMÉ}

On a examiné les résultats des tests sérologiques pour la syphilis chez des malades traités de 1952 à 1966 à la Fondation Hospitalière pour les Maladies Rhumatismales de Heinola, Finlande. Tous furent soumis au test VDRL (Venereal Diseases Research Laboratory) à la cardiolipine; ce test fut positif dans 97 cas $(6,6$ pour mille). Parmi ces cas il y avait 82 malades atteints de polyarthrite rhumatoïde ou de spondylarthrite ankylosante. Des données cliniques et/ou la présence d'anticorps antitréponème ont montré que 60 de ces malades avaient la syphilis. La plupart des réactions faussement positives était transitoire et la fréquence probable des sujets donnant des réactions faussement positives de façon chronique était inférieure à 0,4 pour mille.
La rareza de la falsa positividad cronica de los tests a la cardiolipina $(V D R L)$ en casos de poliartritis reumatoide $y$ de espondilartritis anquilosante

\section{SumARIO}

Se estudiaron los resultados de las reacciones serológicas para la sífilis en enfermos tratados de 1952 a 1966 en la Fundación Reumatológica Hospitalaria de Heinola, Finlandia. Todos fueron sometidos al test $V D R L$ (Venereal Diseases Research Laboratory) a base de cardiolipina, que fué positivo en 97 casos (6,6 por mil). De estos casos, 82 fueron de poliartritis reumatoide 0 de espondilartritis anquilosante. Los datos clínicos y/o la presencia de anticuerpos contra el treponema confirmaron en 60 de estos enfermos el diagnóstico de la sífilis. La mayoría de las falsas reacciones positivas fué transitoria de modo que la incidencia probable de personas cuyos sueros dan una falsa reacción positiva con cronicidad no llega a un 0,4 por mil. 